FESIEE

Fundación Emilio Soldevilla para la Investigación y Desarrollo de la Economia de la Empresa

\section{Management Letters / Cuadernos de Gestión}

\author{
journal homepage: http://www.ehu.eus/cuadernosdegestion/revista/es/
}

ISSN: 1131-6837 / e-ISSN: 1988-2157

\title{
Research trends in technology in the context of smart destinations: a bibliometric analysis and network visualization
}

\section{Tendencias de investigación en tecnología en el contexto de los destinos turísticos inteligentes: un análisis y visualización de red bibliométricos}

\author{
Inés Sustacha*, José Francisco Baños-Pino ${ }^{a}$, Eduardo del Valle \\ a Department of Economics, University of Oviedo. Avenida del Cristo s/n, 33006 Oviedo, Spain - jbanos@uniovi.es - https://orcid.org/0000-0002-3685-7909
}

${ }^{b}$ Department of Business Administration, University of Oviedo. C/ Luis Moya Blanco 261, 33203 Gijón, Spain - valleeduardo@uniovi.es - https://orcid.org/0000-00025084-109X

* Corresponding author: Department of Applied Economics, University of Oviedo. Sistema de Información Turística de Asturias (SITA). Jovellanos Faculty of Commerce, Tourism and Social Sciences. C/ Luis Moya Blanco 261, 33203 Gijón, Spain - sustachaines@uniovi.es - https://orcid.org/0000-0001-9263-1296

\section{A R T I C L E I N F O}

Received 24 May 2021, Accepted 18 November 2021

Available online 10 February 2022

DOI: $10.5295 / \mathrm{cdg} .211501$ is

JEL: L83, O32
A B S T R A C T

Information and communication technologies play a critical role in tourism, providing benefits such as improvement in tourism experiences, co-creation of value, and promotion of the marketing of relationships and phygital experiences, where online and offline environments are combined. In recent years, tourism planning and management through smart destinations has aroused great academic interest by including the dimensions of governance, sustainability, accessibility, innovation, and technology. This work aims to analyse and to visualize the scientific production associated with technology in the context of smart destinations. For this, evaluative and relational bibliometric analysis techniques were applied to the bibliographic data of 395 articles indexed in Scopus and Web of Science up to September 2021. The results indicate that there is considerable growth and that a number of authors, countries, and leading institutions contribute significantly to scientific knowledge. In addition, using two bibliometric software tools, VOSviewer and SciMAT, a co-citation network of authors was built to describe their intellectual structure, and a keyword co-occurrence analysis was performed to identify the main thematic areas. The motor themes that drive the research are the conceptualization of tourist destinations, innovation, and data, while experience is a crosscutting theme. Additionally, some limitations and applications of the research are discussed, as well as the practical implications for destination management.

Keywords: Bibliometrics, Co-Citation, Co-Word Analysis, Smart Destination, Smart Technology, Network Visualisation.

\section{R E S U M E N}

Las tecnologías de la información y la comunicación juegan un importante papel en el turismo aportando beneficios como la mejora de las experiencias turísticas, la co-creación de valor e impulsando el marketing de relaciones y las experiencias phygital, donde se unen los entornos online y offline. En los últimos años, la planificación y gestión turística a través de los destinos inteligentes ha despertado un gran interés académico, al incluir las dimensiones de gobernanza, sostenibilidad, accesibilidad, innovación y tecnología. Este trabajo se plantea como objetivo analizar y visualizar la producción científica asociada a la tecnología en el contexto de los destinos inteligentes. Para ello, se han aplicado técnicas de análisis bibliométrico evaluativas y relacionales a los datos bibliográficos de 395 artículos indexados en Scopus y en Web of Science hasta septiembre de 2021. Los resultados indican que existe un crecimiento considerable y que una serie de autores, países e instituciones líderes contribuyen significativamente al conocimiento científico. Además, utilizando de forma complementaria dos herramientas de software bibliométrico, VOSviewer y SciMAT, se ha construido una red de co-citación de autores para describir su estructura intelectual y un análisis de co-ocurrencia de palabras clave para identificar las principales áreas temáticas. Los temas motores que impulsan la investigación son la conceptualización de los destinos turísticos, la innovación y los datos, mientras que la experiencia es un tema transversal. Adicionalmente, se discuten algunas limitaciones y aplicaciones de la investigación, así como las implicaciones prácticas para la gestión de los destinos.

Palabras clave: Bibliometría, Co-citación, Co-Ocurrencia de Palabras, Destino Turístico Inteligente, Tecnología Inteligente, Visualización de Red. 


\section{INTRODUCTION}

The rapid evolution of the internet and information and communication technologies (ICT) during the last decade have profoundly transformed travel and tourism (Xiang et al. 2015) as well as destinations, leading to the emergence of so-called smart tourism destinations (Jovicic 2019). These destinations can be described as innovative spaces built on a technological infrastructure that guarantees the sustainable development of the territory and accessibility and facilitates the interaction and integration of visitors with the environment, improving their experience at the destination and increasing the quality of life of the residents (López de Ávila and García 2013; Segittur 2015). This new management model has attracted the attention of industry and academia (Gretzel et al. 2015a; Koo et al. 2016), giving rise to an emerging and prolific field of research on smart tourism.

Technology is one of the fundamental pillars on which smart destinations are based and provides benefits such as improvement in tourism experiences (Neuhofer et al. 2012; 2015) and co-creation of value and promotes the marketing of relationships and phygital experiences (Ballina et al. 2019). In addition, it is key to competitiveness and has a recognized role in destination management (Koo et al. 2016). However, the application of smart technologies to destination management is common, so it is important to identify which technologies make a destination smart (Ivars-Baidal et al. 2019) and how they create value for destinations (Del Vecchio et al. 2018a) and their interrelationships with the smart tourism ecosystem. It seems appropriate, therefore, to analyse the existing scientific production and to provide evidence in this sense that allows companies and managers to implement measures with more informed and precise knowledge.

This research uses bibliometric analysis techniques using two complementary software tools, VOSviewer and SciMAT. To answer the above questions, we aim to determine (1) how scientific knowledge about smart destinations and technology has evolved; (2) what is their geographical distribution; (3) the most influential authors, journals, and scientific articles; (4) the intellectual structure; and (5) the conceptual and thematic structure. In recent years, there has been a growing interest in these methods in numerous areas of knowledge. Tourism research has not remained on the side lines (see, for example, Benckendorff 2009; Hall 2011; Benckendorff and Zehrer 2013; Ruhanen et al. 2015; Koseoglu et al. 2016; Leong et al. 2021; Soliman et al. 2021b). In the specific area of smart tourism, an article by Johnson and Samakovlis (2019) is one of the first to provide a greater understanding of smart tourism as a research topic, similar to Mehraliyev et al. (2020), who use mixed methods to identify the main trends and to articulate knowledge domains in this area. The roles of social networks and media (Vargas-Sánchez and Saltos 2019; Nusair 2020), big data (Valencia-Arias et al. 2020a), and augmented reality (Valencia-Arias et al. 2020b) have also been investigated in the development of the concepts of smart cities and smart tourism destinations (Bastidas-Manzano et al. 2021) or the smart tourism experience (Soliman et al. 2021a). However, to the best of our knowledge, no study has focused on systematically and critically analysing the scientific production associated with smart technology, focusing on the destination, understood as the physical space in which tourism activity takes place, which has important implications for its management.

This work is structured in five sections. In this first section, the topic is introduced, and the object of the study is described. The second deals with the theoretical framework, delimiting the concepts of smart destinations and technology while posing the research questions. Next, the methodology used in terms of obtaining the references, the analysis, and the visualization and interpretation of the results is specified. The fourth section presents the results obtained, and finally, the fifth section includes discussion on and the conclusions of the research.

\section{THEORETICAL FRAMEWORK}

\subsection{Smart tourism destinations}

The concept of smart tourism destination derives from the development of smart cities, with a renewed focus on urban planning and management (Ivars-Baidal and Vera-Rebollo 2019) based on the use of ICT in key areas such as the economy, the environment, mobility, and governance to transform the infrastructure and services of cities (Bakici et al. 2013). In a smart city, technology is integrated into the city and is combined with its social components to improve the quality of life of residents and the efficiency of urban services (Buhalis and Amaranggana 2014). These ideas can be extrapolated to tourist destinations, which are often urban areas (Gretzel et al. 2015b). Thus, for Del Chiappa and Baggio (2015), smart destinations result from the application of the principles of smart cities to tourist destinations, where not only residents but also tourists are considered (Gretzel et al. 2015a). For López de Ávila and García (2013), the added value provided by the smart destination is the consideration of the visitor as its centre, uniting the concepts of sustainability, accessibility, knowledge, and technological innovation around tourist destinations.

There are multiple definitions of smart tourism destinations (Table 1) whose common characteristic is to place ICT as a cornerstone in their management to create highly differentiated and competitive services.

Smart tourism can be understood as an ecosystem integrated by a network of smart companies, destinations, and technologies used to create, manage, and offer smart tourism services and experiences that is characterized by an intensive exchange of information and co-creation of value (Gretzel et al. 2015b). The dynamic connection of stakeholders through technological platforms (Buhalis and Amaranggana 2014) and intelligent decision-making derived from the exploitation of big data (Xiang and Fesenmaier 2017; Del Vecchio et al. 2018b) constitute the key principles of smart destinations (Femenia-Serra and Neuhofer 2018). Lamsfus et al. (2015) describe the technological platform that makes destinations smart as a combination of intelligent systems, cloud computing, linked data, social networks, the Internet of Things (IoT), and mobile applications. 
Table 1

Main definitions of smart tourism destinations

\begin{tabular}{ll}
\hline \multicolumn{1}{c}{ Author } & \multicolumn{1}{c}{ Definition } \\
\hline Boes et al. & "Places utilising the available technological tools \\
$(2015$, p. 394) & $\begin{array}{l}\text { and techniques to enable demand and supply to } \\
\text { co-create value, pleasure, and experiences for the } \\
\text { tourist and wealth, profit, and benefits for the } \\
\text { organisations and the destination." }\end{array}$ \\
\hline
\end{tabular}

Buhalis and "Destinations need to interconnect multiple Amaranggana stakeholders through a dynamic platform mediate

(2015, p. 378) by ICT in order to support prompt information exchange regarding tourism activities through machine-to-machine learning algorithm which could enhance their decision making process."

Jovicic (2016, "Is a knowledge-based destination, where ICTs are p. 7) used to provide a technological platform on which information and knowledge relating to tourism activities could be instantly exchange."

Lamsfus et al. "A Tourism Destination is said to be Smart

(2015, p. 367) when it makes intensive use of the technological infrastructure provided by the Smart City in order to: (1) enhance the tourism experience of visitors by personalizing and making them aware of both local and tourism services and products available to them at the destination and (2) by empowering destination management organizations, local institutions and tourism companies to make their decisions and take actions based upon the data produced in within the destination, gathered, managed and processed by means of the technology infrastructure."

Segittur "An innovative tourist area, accessible to everyone, (2015, p. 32) and built on a state-of-the-art technological infrastructure, which guarantees a sustainable development of territory, facilitates the interaction of visitors and their integration in their surroundings and enhances the quality of their experiences at destinations and the residents' quality of life."

Source: Own elaboration

\subsection{Smart tourism technology}

Smart technologies are the basic infrastructure that integrates hardware, software, and networks, the use of travel services, and ICT to provide data in real time to facilitate smarter decision-making from the stakeholders of a destination (Pai et al. 2021). They include a wide variety of solutions such as the IoT, cloud computing, artificial intelligence, mobile devices and applications, big data, Wi-Fi connectivity, virtual reality, augmented reality, chatbots, wearable devices, QR codes, near field communication (NFC), radio frequency identification (RFID), social networks, or beacons (Wang et al. 2013; Gajdošík and Orelová 2020; Shen et al. 2020). They are not a mere technical mechanism of interaction but are, above all, new mixed realities that integrate physical and digital resources to generate an environment of phygital experiences (Ballina et al. 2019).

The influence of technology on tourism is not new. Xiang and Fesenmaier (2017) and Femenia-Serra and Ivars-Baidal (2018) dis- tinguish three phases in the application of technological solutions to tourism. At first, information technology (IT) meant a change in business operations and improved competitiveness through developments such as computerized reservation systems (CRSs) or global distribution systems (GDSs). In the second phase, consumers came to play an active role in the co-creation of their own experiences through technology, a key instrument for innovating and improving co-creation and, therefore, creating richer experiences, adding value for the consumer (Neuhofer et al. 2012). Some of the most significant advances have been social networks and smartphones (Wang et al. 2012; Buhalis 2019), with which users have generated a large amount of content (user-generated content), favouring electronic word-of-mouth (eWOM). All this has given way to a new stage of growing sensorization and ubiquitous connectivity. In this tourism big data environment, data are the basis for the functioning of smart tourism and the means by which destination management can advance towards intelligent decision-making (Gretzel et al. 2015b).

Authors such as No and Kim (2015), Huang et al. (2017), Lee et al. (2018), and Jeong and Shin (2020) evaluate the effectiveness of smart technology for destinations based on their accessibility, informativeness, interactivity, and personalization. Accessibility refers to the ease of access and use of information (No and Kim 2015; Jeong and Shin 2020). Lee et al. (2018) describe informativeness such as volume, frequency, veracity, and accuracy of the information. Interactivity is the degree to which smart technologies can facilitate immediate and active communication with tourists (Huang et al. 2017). Personalization allows visitors to be provided with proposals adapted to their needs (Buhalis and Amaranggana 2015).

However, technology also has a "dark side" (Femenia-Serra and Ivars-Baidal 2018; Buhalis 2019). Xiang et al. (2015), Huang et al. (2017), and González-Reverté et al. (2018), among others, warn of the privacy and security risks related to the use of smart technologies. In particular, location-based services (LBSs) have raised great concern due to the use of the location of users by mobile applications that, in some cases, ends up negatively affecting trust in destinations (Afolabi et al. 2021).

Given the importance and implications of all these issues for destination management, this study aims to evaluate the scope and importance of technology in the framework of smart tourism destinations by answering the following research questions:

RQ1: How has scientific knowledge about smart destinations and technology evolved?

RQ2: What is its geographical distribution?

RQ3: What authors, journals, and scientific articles are most influential?

RQ4: What is its intellectual structure?

RQ5: What is its conceptual and thematic structure?

\section{METHODOLOGY}

\subsection{Obtaining bibliometric data}

To identify the relevant references, a systematic review was performed in Scopus and the Web of Science Core Collection (Classic) applying the guidelines of the Preferred Reporting Items for Systematic reviews and Meta-Analyses (PRISMA) statement (Moher et al. 2009). Following Bastidas-Manzano 
et al. (2021), the term "smart tourism destinations" was the basis of the search strategy, combined in this case with "smart technology". To broaden and complete the search equation, other more specific terms related to smart technology were added.

In addition, the studies had to meet a series of inclusion and exclusion criteria to be eligible (Aguinis et al. 2018; Higgins et al. 2019): (1) no time range was set, and publications indexed up to 22 September 2021, the date on which the consultation was carried out, were included; (2) only peer-reviewed articles published in scientific journals were included since they are considered "certified knowledge", being subjected to critical review and approval by other researchers (Ramos-Rodríguez and Ruiz-Navarro 2004); (3) no thematic area filters were applied due to the transversal nature of tourism; and (4) only articles in English were considered, given that the natural language processing (NLP) algorithms used by the software used for the analysis do not support other languages (Table 2).

Table 2

Methodology for searching bibliometric references

Search terms "Smart tourism destinations" and "smart
technology"

Search field Article Title, Abstract, Keywords (Scopus) Topic (WoS)

Query string ("smart tourism" OR "smart destination") AND ("technolog*” OR "app " OR “ict" OR "internet" OR "digital*” OR "smart*” OR "intelligen*” OR "mobile" OR "device" OR "social network" OR "social media" OR "cloud")

Period time All

Document type Journal articles

Thematic area All

Language English

Search date September 2021

Source: Own elaboration

After these criteria were applied, the search performed in Scopus returned 335 results, while from Web of Science, 327 results were obtained. With these records, a single bibliographic database was compiled in Excel to identify and eliminate duplicates (through the digital object identifier (DOI) and the title of the bibliographic reference). The duplicate records of Scopus were prioritized for the final database since Web of Science includes only the first author of each cited document and, therefore, does not consider the rest of the co-authors for the co-citation analysis. Finally, a total of 395 articles on smart destinations and technology were obtained.

\subsection{Bibliometric analysis}

Bibliometrics is a part of scientometrics that applies mathematical and statistical methods to scientific literature and to the authors who produce it, with the aim of studying and analysing their activity (Pritchard 1969). Bibliometric methods are classified as evaluative or relational (Borgman and Furner 2005; Benckendorff and Zehrer 2013; Koseoglu et al. 2016). Evaluative techniques focus on the impact of academic studies evaluating performance with measures of productivity, impact, and hybrid metrics (Hall 2011). Citation is a fundamental impact metric, and its main purpose is to identify the most influential publications, authors, and documents in a specific field of research (Zupic and Čater 2015).

Relational techniques explore relationships within research, such as the structure of research fields, the emergence of new topics and methods, and patterns of national and international co-authorship (Benckendorff and Zehrer 2013). In this work, two techniques of this type are used: co-citation and co-word analysis.

Co-citation is a co-occurrence relationship that occurs when two items from the existing literature are cited together by a third party (Small 1973; Miguel et al. 2007), in the present case, an author who cites two others (White and Griffith 1981; McCain 1990). This type of analysis assumes that there is a thematic affinity between two or more authors who are co-cited and that the greater the frequency of co-citation, the greater the similarity between them. The objective is to determine the central researchers of a certain discipline based on the co-citations of others.

Co-word analysis is based on the joint appearance of two terms with the purpose of delimiting the conceptual and thematic structure of a scientific domain (Callon et al. 1983). The greater the frequency of the joint appearance of the words is, the greater their linkage (Miguel et al. 2008). As a result, a network of topics and their interrelationships are obtained, which represents the conceptual structure of a field.

\subsection{Visualization of the results}

The references that some authors make to others, as well as between journals or any other type of documents, can be represented by a graph with a network structure (Spinak 1996) that consists of two fundamental elements: nodes, which represent the articles, authors, keywords, etc., and links, also called edges, that connect one or more nodes to each other. To avoid duplication in the records and to correct inconsistencies, it has been necessary to develop a thesaurus for the authors and to normalize the keywords (singular and plural forms, in American and British English, etc.).

To build, visualize and explore the author co-citation network, the free software VOSviewer, developed at the University of Leiden, was used (Van Eck and Waltman 2010, 2014). This program provides visualizations of bibliometric networks through maps based on distance in such a way that the distance between two nodes reflects the strength of the relationship between them. Based on the bibliometric database, VOSviewer performs a cluster analysis, grouping each of the nodes according to patterns of proximity or distance (Waltman et al. 2010), obtaining groups or clusters of similar nodes as a result, differentiated by colours.

Co-word analysis was performed with SciMAT (Science Mapping Analysis Tool, Cobo et al. 2011), an open source software tool (GPLv3) developed at the University of Granada. It allows the creation of a set of clusters that represent sets of textual information that can be understood as semantic or conceptual groups of the different topics discussed, facilitating their interpretation through a strategic diagram that represents the topics based on their density and centrality (Callon et al. 1991). The density refers to the internal strength of the network and can be understood as a measure of the development of the topic. The centrality measures the degree of interaction of a network with others, indicating the importance of a topic in the field of research analysed. 


\section{RESULTS}

\subsection{Evolution of the literature}

Figure 1 shows the annual frequency of publications, to which a moving average trend line has been added to analyse its evolution. The time period for which results have been obtained is nine years, between 2013 and 2021, a result that highlights the novelty of the topic. In the early years, there were very few documents, and they were mostly of a conceptual nature. Since 2015 , scientific production has increased significantly, reaching the maximum number of publications in 2020, with a total of 106 articles.

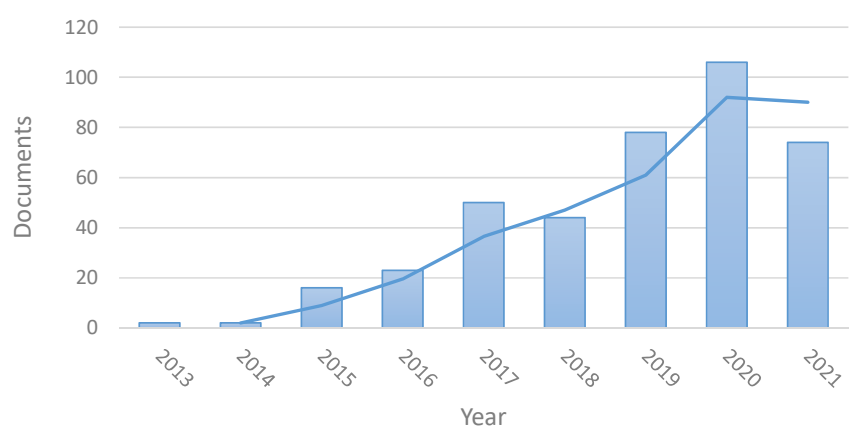

Figure 1

Publications by year

Source: Own elaboration

\subsection{Geographic distribution}

Table 3 offers the distribution of the number of citations by country, which gives an idea of how knowledge about smart destinations is distributed geographically. The works come from 65 different countries, although it seems that there is greater interest in Europe and Asia, which account for $45 \%$ and 34\%, respectively, of the world citations. South Korea is the country with the most citations, followed by the United States and China. In addition, it is necessary to indicate that there are countries that have produced relatively few documents but that have had a notable impact, such as Switzerland, while others, such as Spain or Italy, publish more documents but receive fewer citations. The United Kingdom, Austria, and China have the most recent publications.

Table 3

Main countries

\begin{tabular}{rlrrrr}
\hline \multirow{2}{*}{ Ranking } & Country & Documents & Citations & $\begin{array}{c}\text { Average } \\
\text { citations }\end{array}$ & APY \\
\hline 1 & South Korea & 64 & 2,070 & 32.3 & 2018.0 \\
2 & United States & 47 & 1,993 & 42.4 & 2018.3 \\
3 & China & 65 & 1,331 & 20.5 & 2019.1 \\
4 & Australia & 16 & 1,110 & 69.4 & 2018.4 \\
5 & Spain & 58 & 1,036 & 17.9 & 2018.9 \\
6 & United Kingdom & 25 & 790 & 31.6 & 2019.3 \\
7 & Italy & 30 & 560 & 18.7 & 2018.6 \\
8 & Switzerland & 4 & 503 & 125.8 & 2017.0 \\
9 & Austria & 11 & 348 & 31.6 & 2019.1 \\
10 & Taiwan & 15 & 328 & 21.9 & 2018.0 \\
\hline
\end{tabular}

APY: Average publication year

Source: Own elaboration
Kyung Hee University in South Korea is the institution with the highest number of citations, followed by two Australian universities: The University of Queensland and the University of South Australia. As was the case with countries, certain institutions receive a higher average number of citations, such as Beijing Normal University in China and West Virginia University in the United States. The Hong Kong Polytechnic University and Bournemouth University in the United Kingdom are the institutions with the most recent average year of publication (Table 4).

Table 4

Main institutions

\begin{tabular}{|c|c|c|c|c|c|}
\hline Ranking & Institution & Documents & Citations & $\begin{array}{l}\text { Average } \\
\text { citations }\end{array}$ & APY \\
\hline 1 & $\begin{array}{l}\text { Kyung Hee } \\
\text { University, South } \\
\text { Korea }\end{array}$ & 40 & 1,701 & 42.5 & 2017.8 \\
\hline 2 & $\begin{array}{l}\text { The University } \\
\text { of Queensland, } \\
\text { Australia }\end{array}$ & 4 & 852 & 213.0 & 2015.8 \\
\hline 3 & $\begin{array}{l}\text { University of South } \\
\text { Australia, Australia }\end{array}$ & 2 & 620 & 310.0 & 2016.5 \\
\hline 4 & $\begin{array}{l}\text { Bournemouth } \\
\text { University, United } \\
\text { Kingdom }\end{array}$ & 8 & 606 & 75.8 & 2018.4 \\
\hline 5 & $\begin{array}{l}\text { Virginia Polytechnic } \\
\text { Institute and State } \\
\text { University, United } \\
\text { States }\end{array}$ & 4 & 596 & 149.0 & 2018.0 \\
\hline 6 & $\begin{array}{l}\text { University } \\
\text { of Applied } \\
\text { Sciences Western } \\
\text { Switzerland, } \\
\text { Switzerland }\end{array}$ & 2 & 456 & 228.0 & 2017.5 \\
\hline 7 & $\begin{array}{l}\text { Beijing Normal } \\
\text { University, China }\end{array}$ & 1 & 447 & 447.0 & 2016.0 \\
\hline 8 & $\begin{array}{l}\text { West Virginia } \\
\text { University, United } \\
\text { States }\end{array}$ & 1 & 447 & 447.0 & 2016.0 \\
\hline 9 & $\begin{array}{l}\text { The Hong Kong } \\
\text { Polytechnic } \\
\text { University, Hong } \\
\text { Kong }\end{array}$ & 17 & 352 & 20.7 & 2018.8 \\
\hline 10 & $\begin{array}{l}\text { Capital University } \\
\text { of Economics and } \\
\text { Business, China }\end{array}$ & 2 & 297 & 148.5 & 2015.0 \\
\hline
\end{tabular}

APY: Average publication year

Source: Own elaboration

\subsection{Most influential authors, journals, and articles}

The citation of authors is a metric that allows the determination of who the experts are in a specific field of research. In the case that concerns us, a total of 940 different authors are identified, including Chulmo Koo, from Kyung Hee University (South Korea). Next are Ulrike Gretzel (University of South- 
ern California, United States) and Nahmo Chung (Kyung Hee University, South Korea). It should also be noted that while 805 researchers have published only one article, only twelve have published more than five, and only two (Nahmo Chung and Chulmo Koo) more than ten. That is, most authors publish very few articles, while a small number publish the majority of the relevant works, contributing to a greater extent to the development of knowledge in this field (Lotka 1926). Ulrike Gretzel and Dimitrios Buhalis are the authors with the most recent average publication year (Table 5).

Table 5

Main authors

\begin{tabular}{|c|c|c|c|c|c|c|}
\hline Ranking & Author & Institution & Documents & Citations & Average citations & APY \\
\hline 1 & Chulmo Koo & Kyung Hee University, South Korea & 17 & 1,192 & 70.1 & 2017.4 \\
\hline 2 & Ulrike Gretzel & University of Southern California, United States & 9 & 858 & 95.3 & 2018.0 \\
\hline 3 & Nahmo Chung & Kyung Hee University, South Korea & 25 & 711 & 28.4 & 2017.8 \\
\hline 4 & Marianna Sigala & University of South Australia, Australia & 2 & 620 & 310.0 & 2016.5 \\
\hline 5 & Zheng Xiang & Virginia Polytechnic Institute and State University, United States & 3 & 583 & 194.3 & 2017.7 \\
\hline 6 & Dimitrios Buhalis & Bournemouth University, United Kingdom & 6 & 576 & 96.0 & 2018.0 \\
\hline 7 & Antonio J. Jara & HOP Ubiquitous, Spain & 2 & 456 & 228.0 & 2017.5 \\
\hline 8 & Rongfang Bie & Beijing Normal University, China & 1 & 447 & 447.0 & 2016.0 \\
\hline 9 & Houbing Song & Embry-Riddle Aeronautical University, United States & 1 & 447 & 447.0 & 2016.0 \\
\hline 10 & Yunchuan Sun & Beijing Normal University, China & 1 & 447 & 447.0 & 2016.0 \\
\hline
\end{tabular}

APY: Average publication year

Source: Own elaboration

Among the 179 journals identified, the Journal of Destination Marketing and Management stands out, with a total of 734 citations, followed by Electronic Markets and Sustainability, with 558 and 501 citations, respectively. However, Sustainability has published the greatest number of articles, followed by the International Journal of Tourism Cities and the Journal of Destination Marketing and Management. The journals that have published articles with the most recent average year are Tourism Review and Sustainability (Table 6).

Table 6

Main journals

\begin{tabular}{|c|c|c|c|c|c|}
\hline Ranking & Journal & Documents & Citations & $\begin{array}{l}\text { Average } \\
\text { citations }\end{array}$ & APY \\
\hline 1 & $\begin{array}{l}\text { Journal of } \\
\text { Destination } \\
\text { Marketing and } \\
\text { Management }\end{array}$ & 10 & 734 & 73.4 & 2016.9 \\
\hline 2 & Electronic Markets & 3 & 558 & 186.0 & 2018.3 \\
\hline 3 & Sustainability & 53 & 501 & 9.5 & 2019.2 \\
\hline 4 & IEEE Access & 3 & 453 & 151.0 & 2018.0 \\
\hline 5 & $\begin{array}{l}\text { Computers in } \\
\text { Human Behavior }\end{array}$ & 3 & 440 & 146.7 & 2015.0 \\
\hline 6 & $\begin{array}{l}\text { Tourism } \\
\text { Management }\end{array}$ & 6 & 432 & 72.0 & 2017.7 \\
\hline 7 & $\begin{array}{l}\text { Technological } \\
\text { Forecasting and } \\
\text { Social Change }\end{array}$ & 9 & 324 & 36.0 & 2017.0 \\
\hline 8 & $\begin{array}{l}\text { Information and } \\
\text { Management }\end{array}$ & 4 & 302 & 75.5 & 2017.0 \\
\hline 9 & Tourism Review & 7 & 286 & 40.9 & 2019.7 \\
\hline 10 & $\begin{array}{l}\text { International Journal } \\
\text { of Tourism Cities }\end{array}$ & 11 & 273 & 24.8 & 2018.2 \\
\hline
\end{tabular}

APY: Average publication year

Source: Own elaboration
The citation analysis applied to the articles allows us to determine the recommended "reading list" (Zupic and Čater 2015). In our case, the article by Gretzel et al. (2015a) defines smart tourism and smart destinations as a component. Next, the work of Sun et al. (2016) promotes the concept of smart and connected communities to improve their habitability, preservation, revitalization, and accessibility, and that of Gretzel et al. (2015b) defines the smart tourism ecosystem and is based on the conceptualization of technologies, cities, and smart tourism to anticipate new ways of creating, exchanging, and consuming value (Table 7).

\subsection{Intellectual structure}

To understand the intellectual structure of the literature on smart destinations and technology, a co-citation analysis of authors was performed, examining the characteristics of the citations provided by the bibliography of each document. The VOSviewer software identified a total of 20,879 authors in the references of the 395 documents of the sample. Establishing a threshold of at least 32 shared citations to keep the network relatively clear and to facilitate its interpretation, we obtain a map with 102 authors (Figure 2).

The nodes represent each of the authors, and their size is proportional to the number of shared citations. As a map based on distance, the shorter the distance between two nodes is, the greater the relationship. The links between nodes represent the number of times an author is cited by another. Dimitrios Buhalis, Ulrike Gretzel, Chulmo Koo, Zheng Xiang, Daniel R. Fesenmaier, and Nahmo Chung are the most frequently cited authors. Figure $2 \mathrm{~b}$ shows this fact through the visualization of density. The greater the number of elements close to a node and the higher its co-citation frequency, the closer the colour of the node is to yellow. Thus, a greater intensity is observed in the centre of the network around Buhalis, Gretzel, and Koo and another series of somewhat more peripheral groups is observed around Fesenmaier, Chung, Ivars-Baidal, and Neuhofer. 
Table 7

Main journal articles

\begin{tabular}{|c|c|c|c|c|}
\hline Ranking & Author (year) & Title & Journal & Citations \\
\hline 1 & Gretzel et al. (2015a) & Smart tourism: foundations and developments & Electronic Markets & 546 \\
\hline 2 & Sun et al. (2016) & $\begin{array}{l}\text { Internet of Things and Big Data Analytics for } \\
\text { Smart and Connected Communities }\end{array}$ & IEEE Access & 447 \\
\hline 3 & Gretzel et al. (2015b) & $\begin{array}{l}\text { Conceptual foundations for understanding smart } \\
\text { tourism ecosystems }\end{array}$ & $\begin{array}{l}\text { Computers in Human } \\
\text { Behavior }\end{array}$ & 242 \\
\hline 4 & Buhalis and Foerste (2015) & $\begin{array}{l}\text { SoCoMo marketing for travel and tourism: } \\
\text { Empowering co-creation of value }\end{array}$ & $\begin{array}{l}\text { Journal of Destination } \\
\text { Marketing and Management }\end{array}$ & 198 \\
\hline 5 & Chung et al. (2015) & $\begin{array}{l}\text { Tourists' intention to visit a destination: The role of } \\
\text { augmented reality (AR) application for a heritage site }\end{array}$ & $\begin{array}{l}\text { Computers in Human } \\
\text { Behavior }\end{array}$ & 185 \\
\hline 6 & Boes et al. (2016) & $\begin{array}{l}\text { Smart tourism destinations: ecosystems for } \\
\text { tourism destination competitiveness }\end{array}$ & $\begin{array}{l}\text { International Journal of } \\
\text { Tourism Cities }\end{array}$ & 178 \\
\hline 7 & Chung and Koo (2015) & $\begin{array}{l}\text { The use of social media in travel information } \\
\text { search }\end{array}$ & Telematics and Informatics & 160 \\
\hline 8 & Marine-Roig and Anton Clavé (2015) & $\begin{array}{l}\text { Tourism analytics with massive user-generated } \\
\text { content: A case study of Barcelona }\end{array}$ & $\begin{array}{l}\text { Journal of Destination } \\
\text { Marketing and Management }\end{array}$ & 158 \\
\hline 9 & Li et al. (2017) & $\begin{array}{l}\text { The concept of smart tourism in the context of } \\
\text { tourism information services }\end{array}$ & Tourism Management & 152 \\
\hline 10 & Wang et al. (2013) & $\begin{array}{l}\text { Chinass "smart tourism destination" initiative: A } \\
\text { taste of the service-dominant logic }\end{array}$ & $\begin{array}{l}\text { Journal of Destination } \\
\text { Marketing and Management }\end{array}$ & 145 \\
\hline
\end{tabular}

Source: Own elaboration

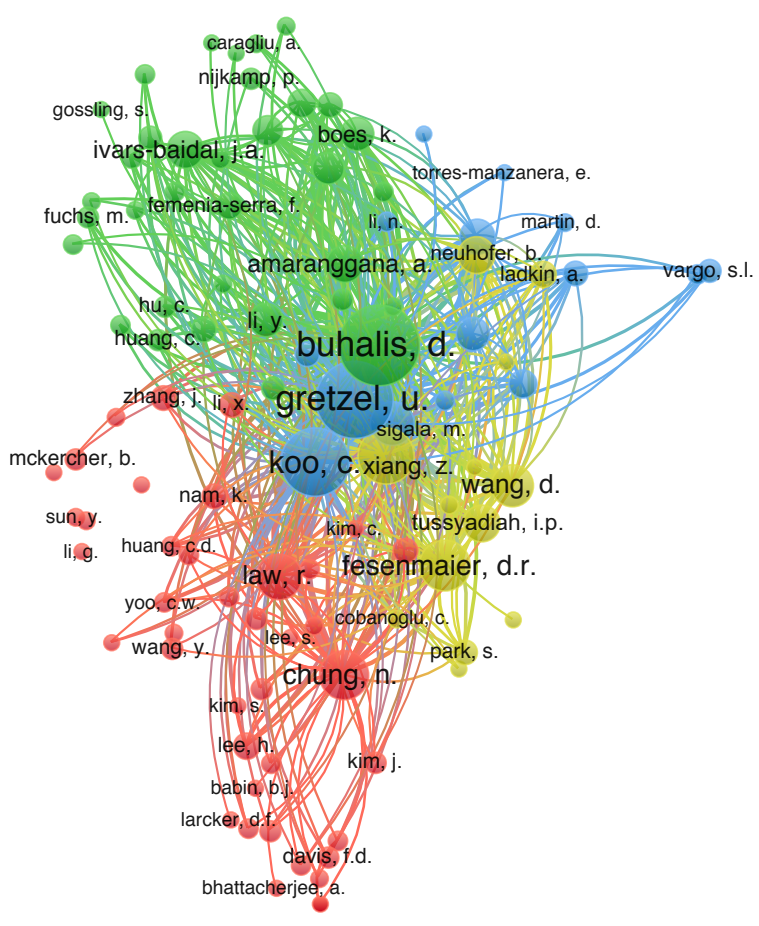

(a)

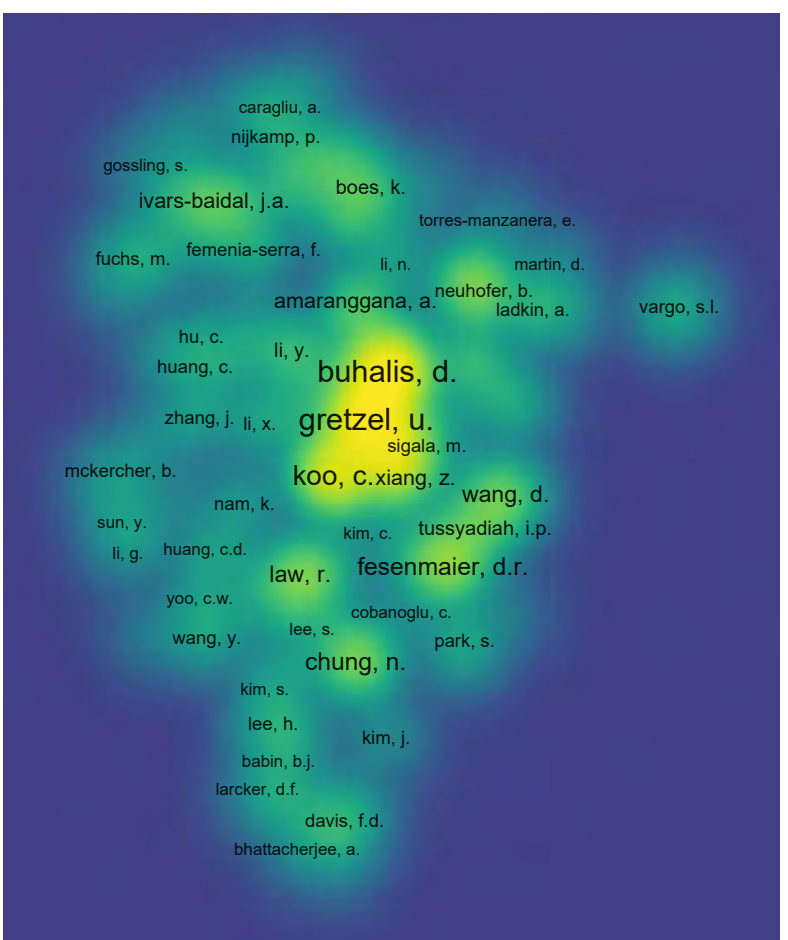

(b)

Figure 2

Author co-citation network

(a): network visualization based on co-occurrences, (b): density visualization map based on co-occurrences Source: Own elaboration 
The four clusters in which the authors are grouped are represented by different colours (Figure 2a). Cluster 1 (red) is formed by 40 authors, among which Nahmo Chung stands out, with interests in e-tourism, technology adoption, knowledge management, and travel behaviour. Closer to the centre of the network is Rob Law, with work more related to the management of technology in tourism and hospitality. Cluster 2 (green) includes 34 authors, where Dimitrios Buhalis, known for his work in information technologies applied to tourism from the perspective of marketing, plays a central role and is very close to Aditya Amaranggana. In this group, although occupying a much more peripheral position, there is also Josep Antoni Ivars-Baidal, and other authors are clearly oriented towards destination management. Cluster 3 (blue) contains 15 authors, including Ulrike Gretzel, one of the researchers who has contributed the most to the conceptualization of smart tourism, very close to Chulmo Koo and Mariana Sigala. Cluster 4 (yellow) groups 13 authors, with Zheng Xiang, who serves as a bridge to others less central but with a notable number of co-citations such as Daniel R. Fesenmaier, Iis P. Tussyadiah, and Dan Wang. The work of these authors is mainly oriented towards destination marketing and the influence of ICT on consumer behaviour and the travel experience.

\subsection{Conceptual and thematic structure}

To identify the topics of greatest interest to academics at the intersection between smart destinations and technology, a coword analysis was performed. After the normalization carried out with SciMAT, we identified a total of 1,148 keywords, from which the strategic diagram of Figure 3 was obtained based on the number of documents.

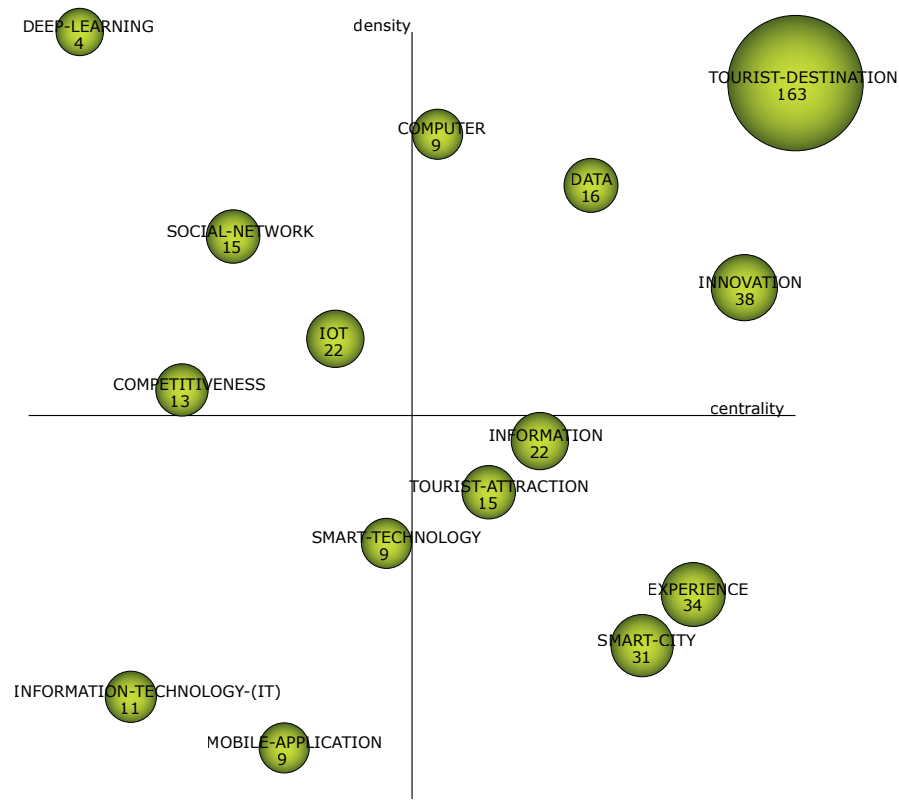

Figure 3

Strategic diagram of the conceptual structure Source: Own elaboration
The research is structured into 15 topics. The combination of high and low levels of density and centrality allows the strategic diagram to be divided into four groups. The motor themes (upper right quadrant) are tourist destination, innovation, data, and computer. They are well-developed topics characterized by high centrality and density and constitute the basis of the structure of the research field. The basic and transversal themes (lower right quadrant) are experience, smart city, information, and tourist attraction. They are important for the scientific field, but they are not well developed; that is, they are transversal and general topics with high centrality and low density. On the other hand, Information Technology (IT), mobile application, and smart technology are emerging or declining topics (lower left quadrant). They correspond to very underdeveloped and secondary themes, with low density and centrality. Finally, there are four peripheral themes (upper left quadrant) that are well developed internally but isolated from the rest and have marginal importance: the Internet of Things (IoT), social network, competitiveness, and deep learning. They are characterized by highly specialized topics with high density and low centrality. Table 8 shows the main impact metrics of these 15 thematic areas.

Table 8

Impact metrics of the thematic areas

\begin{tabular}{lrrrr}
\hline \multicolumn{1}{c}{ Theme } & Documents & h-Index & $\begin{array}{c}\text { Average } \\
\text { citations }\end{array}$ & Citations \\
\hline Tourist destination & 163 & 26 & 15.98 & 2,605 \\
Innovation & 38 & 12 & 11.39 & 433 \\
Experience & 34 & 10 & 8.91 & 303 \\
Smart city & 31 & 11 & 31.65 & 981 \\
Information & 22 & 10 & 27.36 & 602 \\
Internet of things (IoT) & 22 & 10 & 60.82 & 1,338 \\
Data & 16 & 7 & 22.50 & 360 \\
Social network & 15 & 11 & 21.73 & 326 \\
Tourist attraction & 15 & 6 & 12.67 & 190 \\
Competitiveness & 13 & 5 & 9.00 & 117 \\
Information & 11 & 6 & 14.00 & 154 \\
technology (IT) & 9 & 4 & 6.44 & 58 \\
Computer & 9 & 5 & 95.44 & 859 \\
Smart technology & 9 & 5 & 4.11 & 37 \\
Mobile application & 4 & 2 & 4.50 & 18 \\
Deep learning & & & &
\end{tabular}

Source: Own elaboration

\section{DISCUSSION AND CONCLUSIONS}

Smart destinations have been consolidated as a new paradigm for management with governance, sustainability, accessibility, innovation, and technology as backbones. The transformation of a destination into a smart destination implies an increase in competitiveness, an enhancement in the efficiency of production and marketing processes, a boost to sustainable development, an improvement in the visitor experience and the quality of life of residents, and, ultimately, the economic revitalization of the territory. Therefore, they have had notable success, with a growing number of destinations interested in implementing a smart 
strategy, while they have managed to awaken the interest of the scientific community.

This work uses evaluative and relational bibliometric analysis techniques to analyse 395 articles on technology and smart tourism destinations indexed in Scopus and Web of Science up to September 2021. According to the research carried out, the evolution of scientific knowledge in this field (research question 1) reveals that it is a fairly novel topic, with a quantitative leap in the literature since 2015, and that it has a considerable growth trend, evidencing the interest it has aroused in academia (Gretzel et al. 2015a; Koo et al. 2016).

The analysis also allows the identification of the countries and organizations from which the most relevant publications come, answering research question 2 . The studies with the greatest impact come from South Korea, the United States, and China. This fact is also reflected in the institutions that contribute the most to scientific knowledge, with Kyung Hee University of South Korea as the leader, followed by two Australian universities: The University of Queensland and the University of South Australia.

The citation analysis determines which authors, journals, and articles are more prominent (research question 3). Chulmo Koo, Ulrike Gretzel, and Nahmo Chung are the most influential authors. Among the main journals, Journal of Destination Marketing and Management is the publication with the highest impact in terms of number of citations, while Sustainability is the one with the largest number of articles. The most relevant work is that of Gretzel et al. (2015a), where smart tourism is defined and its technological and business foundations are exposed. The articles by Sun et al. (2016), which promotes the concept of smart and connected communities, and that of Gretzel et al. (2015b), which defines the smart tourism ecosystem, are also especially important.

The exploration of author co-citation patterns has answered research question 4 about the intellectual structure of the literature. The authors are grouped into four clusters oriented towards e-tourism, marketing, the conceptualization of smart tourism, and consumer behaviour and their travel experience.

Regarding the conceptual and thematic structure (research question 5), according to the co-word analysis and its performance and impact, there are five important topics that have focused the research on smart destinations and technology: two are major topics, tourist destination and innovation, two others are transversal ones, experience and smart city, and the last is peripheral, Internet of Things (IoT).

Technology occupies a prominent place in the literature on smart tourism (Gretzel et al. 2015a; Gretzel et al. 2015b; Li et al. 2017) and smart destinations (Wang et al. 2013; Buhalis and Amaranggana 2014; Boes et al. 2015; Jovicic 2016), especially in regard to its conceptual development but also in the management of destinations (Koo et al. 2016; Kim et al. 2017), where according to Ivars-Baidal et al. (2019), technological solutions can provide substantial improvements in tourism information, experience, marketing, visitor management and tourism intelligence. For Gretzel et al. (2016), from the business point of view, smart tourism allows new ways of managing tourism flows, leading to the emergence of new advertising models and collaborative companies that use cloud services and open data to innovate beyond the traditional limits of the sector.
Data, particularly big data, are a driving force in the debate on technology and smart destinations. Big data resulting from user-generated content, its aggregation, analysis (data mining, sentiment analysis...), and intelligent use have become one of the main drivers of value creation in smart destinations (Del Vecchio et al. 2018a), improving decision-making, enriching the tourism experience, promoting new business models and new products and services, and interconnecting the business ecosystem (Secundo et al. 2017).

The improvement in experience as a result of the mediation of technology is one of the most relevant topics and has been addressed in numerous studies (see, for example, Neuhofer et al. 2012, 2015; or Femenia-Serra and Neuhofer 2018). In the context of smart tourism, value creation consists of providing tourists with a "smart experience" (Buhalis and Amaranggana 2015) that depends on the ability of destinations to aggregate information, create ubiquitous connectivity, and synchronize information in real time (Neuhofer et al. 2015). This is especially important since according to Chen (2020), Jeong and Shin (2020), and Pai et al. (2021), the smart tourism experience has a direct impact on tourist satisfaction and on their intention to visit a destination again, so for Buhalis and Amaranggana (2015), improving the experience is a critical issue for destination management organizations (DMOs).

According to the results, the smart destinations model stands as a conceptual but also applied contribution based on the use of data, technology, and interaction with the smart tourism ecosystem, which results in improved public-private management according to Ivars-Baidal et al. (2019). An example of this has been the management of the COVID-19 crisis, where smart destinations, through technological solutions of geolocation (Radojević et al. 2020) and smart governance (Choi et al. 2021), are oriented towards recovering trust (Sánchez-Teba et al. 2020), and managing the flows of people, controlling capacity, or avoiding saturation are good means for maintaining the competitiveness of companies and making destinations safer, more reliable, and more sustainable and efficient.

The strategic diagram confirms the existence of well-established topics in the scientific literature on technology and smart destinations, but there are also others that offer opportunities for future research. In this sense, it would be interesting to advance in the development of tools or indicators that provide destination managers with a measure of their performance when implementing a smart strategy and that allow comparing their degree of smartness (Huertas et al. 2019). As stated by Ivars-Baidal et al. (2021), smart destinations lack a complete set of indicators that evaluate their performance in areas in which they are expected to make efforts, such as connectivity, the treatment of big data, technological deployment, and its interrelation with sustainability and accessibility.

The type of bibliometric analysis performed is not exempt, however, from certain limitations. Although the search equation is carefully constructed, documents that are not within the scope of the study can be obtained by introducing outliers (Zupic and Čater 2015). Therefore, to filter unwanted documents, minimum thresholds are established for the co-citation of authors and coword analysis of keywords. However, without a doubt, the main limitation of this work lies in the very novelty of the research field. 
Most of the publications are very recent and have had little time to be cited. In this sense, both citation and co-citation, although they are widely used and validated methods (Miguel et al. 2007), are biased towards older publications. Future studies may offer a much more complete view of technology and smart destinations.

\section{REFERENCES}

Afolabi, O. O., Ozturen, A. and Ilkan, M., 2021. Effects of privacy concern, risk, and information control in a smart tourism destination. Economic Research-Ekonomska Istraživanja, 34(1), 3119-3138. DOI: 10.1080/1331677X.2020.1867215

Aguinis, H., Ramani, R. S. and Alabduljader, N., 2018. What you see is what you get? Enhancing methodological transparency in management research. Academy of Management Annals, 12(1), 83-110. DOI: 10.5465/annals.2016.0011

Bakici, T., Almirall, E. and Wareham, J., 2013. A Smart City Initiative: The Case of Barcelona. Journal of the Knowledge Economy, 4(2), 135-148. DOI: 10.1007/s13132-012-0084-9

Ballina, F. J., Valdés, L. and Del Valle, E., 2019. The Phygital experience in the smart tourism destination. International Journal of Tourism Cities, 5(4), 656-671. DOI: 10.1108/IJTC-11-2018-0088

Bastidas-Manzano, A. B., Sánchez-Fernández, J. and Casado-Aranda, L.-A., 2021. The Past, Present, and Future of Smart Tourism Destinations: A Bibliometric Analysis. Journal of Hospitality \& Tourism Research, 45(3), 529-552. DOI: 10.1177/1096348020967062

Benckendorff, P. and Zehrer, A., 2013. A network analysis of tourism research. Annals of Tourism Research, 43, 121-149. DOI: 10.1016/j. annals.2013.04.005

Benckendorff, P., 2009. Themes and trends in Australian and New Zealand tourism research: A social network analysis of citations in two leading journals (1994-2007). Journal of Hospitality and Tourism Management, 16(1), 1-15. DOI: 10.1375/jhtm.16.1.1

Boes, K., Buhalis, D. and Inversini, A., 2015. Conceptualising Smart Tourism Destination Dimensions. In: Tussyadiah, I. and Inversini, A. (eds.). Information and Communication Technologies in Tourism 2015. Cham: Springer International Publishing, 391-403. DOI: 10.1007/978-3-319-14343-9_29

Boes, K., Buhalis, D. and Inversini, A., 2016. Smart tourism destinations: ecosystems for tourism destination competitiveness. International Journal of Tourism Cities, 2(2), 108-124. DOI: 10.1108/IJTC12-2015-0032

Borgman, C. L. and Furner, J., 2005. Scholarly Communication and Bibliometrics. Annual Review of Information Science and Technology, 36(1), 2-72. DOI: 10.1002/aris.1440360102

Buhalis, D. and Amaranggana, A., 2014. Smart Tourism Destinations. In: Xiang, Z. and Tussyadiah, I. (eds.). Information and Communication Technologies in Tourism 2014. Cham: Springer, 553-564. DOI: 10.1007/978-3-319-03973-2_40

Buhalis, D. and Amaranggana, A., 2015. Smart Tourism Destinations Enhancing Tourism Experience Through Personalisation of Services. In: Tussyadiah, I. and Inversini, A. (eds.). Information and Communication Technologies in Tourism 2015. Cham: Springer, 377-389. DOI: 10.1007/978-3-319-14343-9_28

Buhalis, D. and Foerste, M., 2015. SoCoMo marketing for travel and tourism: Empowering co-creation of value. Journal of Destination Marketing \& Management, 4(3), 151-161. DOI: 10.1016/j. jdmm.2015.04.001

Buhalis, D., 2019. Technology in tourism-from information communication technologies to eTourism and smart tourism towards ambient intelligence tourism: a perspective article. Tourism Review, 75(1), 267-272. DOI: 10.1108/TR-06-2019-0258
Callon, M., Courtial, J.-P. and Laville, F., 1991. Co-word analysis as a tool for describing the network of interactions between basic and technological research: The case of polymer chemsitry. Scientometrics, 22(1), 155-205. DOI: 10.1007/BF02019280

Callon, M., Courtial, J.-P., Turner, W. A. and Bauin, S., 1983. From translations to problematic networks: An introduction to coword analysis. Social Science Information, 22(2), 191-235. DOI: $10.1177 / 053901883022002003$

Chen, C., 2020. The Influence of Smart Tourism on Tourist Experience Toward Travel Intention and Satisfaction: Evidence from China. International Journal of Marketing Studies, 12(3), 65-70. DOI: 10.5539/ijms.v12n3p65

Choi, J., Lee, S. and Jamal, T., 2021. Smart Korea: Governance for smart justice during a global pandemic. Journal of Sustainable Tourism, 29(2-3), 540-549. DOI: 10.1080/09669582.2020.1777143

Chung, N. and Koo, C., 2015. The use of social media in travel information search. Telematics and Informatics, 32(2), 215-229. DOI: $10.1016 /$ j.tele.2014.08.005

Chung, N., Han, H. and Joun, Y., 2015. Tourists' intention to visit a destination: The role of augmented reality (AR) application for a heritage site. Computers in Human Behavior, 50, 588-599. DOI: 10.1016/j.chb.2015.02.068

Cobo, M. J., López-Herrera, A. G., Herrera-Viedma, E. and Herrera, F., 2011. An approach for detecting, quantifying, and visualizing the evolution of a research field: A practical application to the Fuzzy Sets Theory field. Journal of Informetrics, 5(1), 146-166. DOI: 10.1016/j.joi.2010.10.002

Del Chiappa, G. and Baggio, R., 2015. Knowledge transfer in smart tourism destinations: Analyzing the effects of a network structure. Journal of Destination Marketing and Management, 4(3), 145-150. DOI: 10.1016/j.jdmm.2015.02.001

Del Vecchio, P., Mele, G., Ndou, V. and Secundo, G., 2018a. Creating value from Social Big Data: Implications for Smart Tourism Destinations. Information Processing \& Management, 54(5), 847-860. DOI: 10.1016/j.ipm.2017.10.006

Del Vecchio, P., Mele, G., Ndou, V., Passiante, G. and Secundo, G., 2018b. Knowledge-intensive entrepreneurship and Big Data: implications for smart tourism destinations. In: Vrontis, D., Weber, Y. and Tsoukatos, E. (eds.). Research Advancements in National and Global Business Theory and Practice. Valletta: EuroMed Press, 440-453.

Femenia-Serra, F. and Ivars-Baidal, J. A., 2018. Smart tourism: Implicaciones para la gestión de ciudades y destinos turísticos. In: Cantó López, M. T., Ivars-Baidal, J. A. and Martínez Gutiérrez, R. (eds.). Gestión inteligente y sostenible de las ciudades: Gobernanza, smart cities y turismo. Valencia: Tirant Lo Blanch, 129-151.

Femenia-Serra, F. and Neuhofer, B., 2018. Smart tourism experiences: Conceptualisation, key dimensions and research agenda. Investigaciones Regionales, 42, 129-150.

Gajdošík, T. and Orelová, A., 2020. Smart Technologies for Smart Tourism Development. In: Silhavy, R. (ed.). Advances in Intelligent Systems and Computing. Cham: Springer Nature Switzerland, 333-343. DOI: 10.1007/978-3-030-51971-1_27

González-Reverté, F., Díaz-Luque, P., Gomis-López, J. M. and Morales-Pérez, S., 2018. Tourists' risk perception and the use of mobile devices in beach tourism destinations. Sustainability, 10(2). DOI: $10.3390 /$ su10020413

Gretzel, U., Sigala, M., Xiang, Z. and Koo, C., 2015a. Smart tourism: foundations and developments. Electronic Markets, 25(3), 179-188. DOI: $10.1007 / \mathrm{s} 12525-015-0196-8$

Gretzel, U., Werthner, H., Koo, C. and Lamsfus, C., 2015b. Conceptual foundations for understanding smart tourism ecosystems. Computers in Human Behavior, 50, 558-563. DOI: 10.1016/j. chb.2015.03.043 
Gretzel, U., Zhong, L. and Koo, C., 2016. Application of smart tourism to cities. International Journal of Tourism Cities, 2(2), 216-233. DOI: 10.1108/IJTC-04-2016-0007

Hall, C. M., 2011. Publish and perish? Bibliometric analysis, journal ranking and the assessment of research quality in tourism. Tourism Management, 32(1), 16-27. DOI: 10.1016/j.tourman.2010.07.001

Higgins, J. P. T., Thomas, J., Chandler, J., Cumpston, M., Li, T., Page, M. and Welch, V. (eds.), 2019. Cochrane Handbook for Systematic Reviews of Interventions. 2nd Edition. Chichester: John Wiley \& Sons.

Huang, C. D., Goo, J., Nam, K. and Yoo, C. W., 2017. Smart tourism technologies in travel planning: The role of exploration and exploitation. Information \& Management, 54(6), 757-770. DOI: 10.1016/j. im.2016.11.010

Huertas, A., Moreno, A. and Ha My, T., 2019. Which destination is smarter? Application of the (SA)6 framework to establish a ranking of smart tourist destinations. International Journal of Information Systems and Tourism, 4(1), 19-28.

Ivars-Baidal, J. A. and Vera-Rebollo, J. F., 2019. Tourism planning in Spain. From traditional paradigms to new approaches: smart tourism planning. Boletín de la Asociación de Geógrafos Españoles, 82 , 1-31. DOI: $10.21138 /$ bage.2765

Ivars-Baidal, J. A., Celdrán-Bernabeu, M. A., Femenia-Serra, F., Perles-Ribes, J. F. and Giner-Sánchez, D., 2021. Measuring the progress of smart destinations: The use of indicators as a management tool. Journal of Destination Marketing \& Management, 19, 100531. DOI: 10.1016/j.jdmm.2020.100531

Ivars-Baidal, J. A., Celdrán-Bernabeu, M. A., Mazón, J.-N. and Perles-Ivars, Á. F., 2019. Smart destinations and the evolution of ICTs: a new scenario for destination management? Current Issues in Tourism, 22(13), 1581-1600. DOI: 10.1080/13683500.2017.1388771

Jeong, M. and Shin, H. H., 2020. Tourists' Experiences with Smart Tourism Technology at Smart Destinations and Their Behavior Intentions. Journal of Travel Research, 59(8), 1464-1477. DOI $10.1177 / 0047287519883034$

Johnson, A.-G. and Samakovlis, I., 2019. A bibliometric analysis of knowledge development in smart tourism research. Journal of Hospitality and Tourism Technology, 10(4), 600-623. DOI: 10.1108/ JHTT-07-2018-0065

Jovicic, D. Z., 2016. Key issues in the conceptualization of tourism destinations. Tourism Geographies, 18(4), 445-457. DOI $10.1080 / 14616688.2016 .1183144$

Jovicic, D. Z., 2019. From the traditional understanding of tourism destination to the smart tourism destination. Current Issues in Tourism, 22(3), 276-282. DOI: 10.1080/13683500.2017.1313203

Kim, K., Park, O., Yun, S. and Yun, H., 2017. What makes tourists feel negatively about tourism destinations? Application of hybrid text mining methodology to smart destination management. Technological Forecasting and Social Change, 123, 362-369. DOI: 10.1016/j. techfore.2017.01.001

Koo, C., Shin, S., Gretzel, U., Hunter, W. C. and Chung, N., 2016. Conceptualization of Smart Tourism Destination Competitiveness. Asia Pacific Journal of Information Systems, 26(4), 367-384. DOI: 10.14329/apjis.2016.26.4.367

Koseoglu, M. A., Rahimi, R., Okumus, F. and Liu, J., 2016. Bibliometric studies in tourism. Annals of Tourism Research, 61, 180-198. DOI: 10.1016/j.annals.2016.10.006

Lamsfus, C., Martín, D., Alzua-Sorzabal, A. and Torres Manzanera, E., 2015. Smart tourism destinations: An extended conception of smart cities focusing on human mobility. In: Tussyadiah, I. and Inversini, A. (eds.). Information and Communication Technologies in Tourism 2015. Cham: Springer International Publishing, 363-375. DOI 10.1007/978-3-319-14343-9_27
Lee, H., Lee, J., Chung, N. and Koo, C., 2018. Tourists' happiness: are there smart tourism technology effects? Asia Pacific Journal of Tourism Research, 23(5), 486-501. DOI: 10.1080/10941665.2018.1468344

Leong, L.-Y., Hew, T.-S., Tan, G. W.-H., Ooi, K.-B. and Lee, V.-H., 2021. Tourism research progress - a bibliometric analysis of tourism review publications. Tourism Review, 76(1), 1-26. DOI: 10.1108/TR11-2019-0449

Li, Y., Hu, C., Huang, C. and Duan, L., 2017. The concept of smart tourism in the context of tourism information services. Tourism Management, 58, 293-300. DOI: 10.1016/j.tourman.2016.03.014

López de Ávila, A. and García, S., 2013. Destinos turísticos inteligentes. Economía Industrial, 395, 61-69.

Lotka, A. J., 1926. The frequency distribution of scientific productivity. Journal of the Washington Academy of Sciences, 16(12), 317-323.

Marine-Roig, E. and Anton Clavé, S., 2015. Tourism analytics with massive user-generated content: A case study of Barcelona. Journal of Destination Marketing and Management, 4(3), 162-172. DOI: 10.1016/j.jdmm.2015.06.004

McCain, K. W., 1990. Mapping authors in intellectual space: a technical overview. Journal of the American Society for Information Science, 41(6), 433-443. DOI: 10.1002/(SICI)1097-4571(199009)41:6<433: AID-ASI11>3.0.CO;2-Q

Mehraliyev, F., Chan, I. C. C., Choi, Y., Koseoglu, M. A. and Law, R., 2020. A state-of-the-art review of smart tourism research. Journal of Travel \& Tourism Marketing, 37(1), 78-91. DOI: 10.1080/10548408.2020.1712309

Miguel, S., Caprile, L. and Jorquera-Vidal, I., 2008. Análisis de co-términos y de redes sociales para la generación de mapas temáticos. El Profesional de la Información, 17(6), 637-646. DOI: 10.3145/epi.2008.nov.06

Miguel, S., Moya-Anegón, F. and Herrero-Solana, V., 2007. El análisis de co-citas como método de investigación en Bibliotecología y Ciencia de la Información. Investigación Bibliotecológica, 21(43), 139-155.

Moher, D., Liberati, A., Tetzlaff, J., Altman, D. G. and The PRISMA Group, 2009. Preferred Reporting Items for Systematic Reviews and Meta-Analyses: The PRISMA Statement. PLoS Med, 6(7), e1000097. DOI: 10.1371/journal.pmed.1000097

Neuhofer, B., Buhalis, D. and Ladkin, A., 2012. Conceptualising technology enhanced destination experiences. Journal of Destination Marketing and Management, 1(1-2), 36-46. DOI: 10.1016/j. jdmm.2012.08.001

Neuhofer, B., Buhalis, D. and Ladkin, A., 2015. Smart technologies for personalized experiences: a case study in the hospitality domain. Electronic Markets, 25(3), 243-254. DOI: 10.1007/s12525-015-0182-1

No, E. and Kim, J. K., 2015. Comparing the attributes of online tourism information sources. Computers in Human Behavior, 50, 564-575. DOI: $10.1016 /$ j.chb.2015.02.063

Nusair, K., 2020. Developing a comprehensive life cycle framework for social media research in hospitality and tourism. International Journal of Contemporary Hospitality Management, 32(3), 1041-1066. DOI: 10.1108/IJCHM-09-2019-0777

Pai, C.-K., Kang, S., Liu, Y. and Zheng, Y., 2021. An Examination of Revisit Intention Based on Perceived Smart Tourism Technology Experience. Sustainability, 13(2), 1007. DOI: 10.3390/su13021007

Pritchard, A., 1969. Statistical bibliography or bibliometrics? Journal of Documentation, 25(4), 348-349.

Radojević, B., Lazić, L. and Cimbaljević, M., 2020. Rescaling smart destinations: The growing importance of smart geospatial services during and after COVID-19 pandemic. Geographica Pannonica, 24(3), 221-228. DOI: $10.5937 / g p 24-28009$

Ramos-Rodríguez, A. R. and Ruiz-Navarro, J., 2004. Changes in the intellectual structure of strategic management research: A bibliometric study of the Strategic Management Journal, 1980-2000. Strategic Management Journal, 25(10), 981-1004. DOI: 10.1002/smj.397 
Ruhanen, L., Weiler, B., Moyle, B. D. and McLennan, C. J., 2015. Trends and patterns in sustainable tourism research: a 25 -year bibliometric analysis. Journal of Sustainable Tourism, 23(4), 517-535. DOI 10.1080/09669582.2014.978790

Sánchez-Teba, E. M., García-Mestanza, J. and Rodríguez-Fernández, M., 2020. The Application of the Inbound Marketing Strategy on Costa del Sol Planning \& Tourism Board. Lessons for Post-COVID-19 Revival. Sustainability, 12(23), 9926. DOI: 10.3390/su12239926

Secundo, G., Del Vecchio, P., Dumay, J. and Passiante, G., 2017. Intellectual capital in the age of Big Data: establishing a research agenda. Journal of Intellectual Capital, 18(2), 242-261. DOI: 10.1108/JIC-10-2016-0097

Segittur, 2015. Informe destinos turísticos inteligentes: construyendo el futuro. Madrid: Sociedad Estatal para la Gestión de la Innovación y las Tecnologías Turísticas. Available at: https://www.segittur.es/ wp-content/uploads/2019/11/Libro-Blanco-Destinos-Tursticos-Inteligentes.pdf [Access: $17^{\text {th }}$ May 2021]

Shen, S., Sotiriadis, M. and Zhang, Y., 2020. The Influence of Smart Technologies on Customer Journey in Tourist Attractions within the Smart Tourism Management Framework. Sustainability, 12(10), 4157. DOI: $10.3390 /$ su12104157

Small, H., 1973. Co-citation in the scientific literature: A new measure of the relationship between two documents. Journal of the American Society for Information Science, 24(4), 265-269. DOI: 10.1002/ asi.4630240406

Soliman, M., Cardoso, L., Almeida, G. G. F., Araújo, A. F. and Araújo Vila, N., 2021a. Mapping smart experiences in tourism: A bibliometric approach. European Journal of Tourism Research, 28, 2809.

Soliman, M., Lyulyov, O., Shvindina, H., Figueiredo, R. and Pimonenko, T., 2021b. Scientific output of the European Journal of Tourism Research: A bibliometric overview and visualization. European Journal of Tourism Research, 28, 2801.

Spinak, E., 1996. Diccionario Enciclopédico de Bibliometría, Cienciometría e Informetría. Venezuela: UNESCO.

Sun, Y., Song, H., Jara, A. J. and Bie, R., 2016. Internet of Things and Big Data Analytics for Smart and Connected Communities. IEEE Access, 4, 766-773. DOI: 10.1109/ACCESS.2016.2529723

Valencia-Arias, A., Ocampo-Osorio, C., Quiroz-Fabra, J., Garcés-Giraldo, L. F. and Valencia, J., 2020a. Big data research trends in the tourism context: A bibliometric analysis. RISTI-Revista Ibérica de Sistemas e Tecnologias de Informação, 36, 243-256.
Valencia-Arias, A., Ocampo-Osorio, C., Quiroz-Fabra, J., Garcés-Giraldo, L. F. and Valencia, J., 2020b. Research trends in augmented reality in tourism: A bibliometric analysis. RISTI-Revista Ibérica de Sistemas e Tecnologias de Informação, 36, 229-242.

Van Eck, N. J. and Waltman, L., 2010. Software survey: VOSviewer, a computer program for bibliometric mapping. Scientometrics, 84(2), 523-538. DOI: $10.1007 / \mathrm{s} 11192-009-0146-3$

Van Eck, N. J. and Waltman, L., 2014. Visualizing Bibliometric Networks. In: Ding, Y., Rousseau, R. and Wolfram, D. (eds.). Measuring scholarly impact: Methods and practice. Cham: Springer, 285-320. DOI: 10.1007/978-3-319-10377-8_13

Vargas-Sánchez, A. and Saltos, A. E., 2019. Smartness and social networks as shapers of the tourism industry: What is being done in Academia in this intersection? Worldwide Hospitality and Tourism Themes, 11(6), 748-759. DOI: 10.1108/WHATT-09-2019-0057

Waltman, L., Van Eck, N. J. and Noyons, E. C. M., 2010. A unified approach to mapping and clustering of bibliometric networks. Journal of Informetrics, 4(4), 629-635. DOI: 10.1016/j.joi.2010.07.002

Wang, D., Li, X. and Li, Y., 2013. China's "smart tourism destination" initiative: A taste of the service-dominant logic. Journal of Destination Marketing \& Management, 2(2), 59-61. DOI: 10.1016/j. jdmm.2013.05.004

Wang, D., Park, S. and Fesenmaier, D. R., 2012. The Role of Smartphones in Mediating the Touristic Experience. Journal of Travel Research, 51(4), 371-387. DOI: 10.1177/0047287511426341

White, H. D. and Griffith, B. C., 1981. Author cocitation: A literature measure of intellectual structure. Journal of the American Society for Information Science, 32(3), 163-171. DOI: 10.1002/ asi.4630320302

Xiang, Z. and Fesenmaier, D. R., 2017. Big Data Analytics, Tourism Design and Smart Tourism. In: Xiang, Z. and Fesenmaier, D. R. (eds.). Analytics in Smart Tourism Design. Cham: Springer, 299-307. DOI: 10.1007/978-3-319-44263-1_17

Xiang, Z., Wang, D., O'Leary, J. T. and Fesenmaier, D. R., 2015. Adapting to the Internet: Trends in Travelers' Use of the Web for Trip Planning. Journal of Travel Research, 54(4), 511-527. DOI: 10.1177/0047287514522883

Zupic, I. and Čater, T., 2015. Bibliometric Methods in Management and Organization. Organizational Research Methods, 18(3), 429-472. DOI: $10.1177 / 1094428114562629$ 


\section{APPENDIX}

Table A.1

Authors co-citation analysis

\begin{tabular}{|c|c|}
\hline Cluster & Author (N) \\
\hline 1 (Red) & $\begin{array}{l}\text { Chung, N. (309), Law, R. (280), Lee, H. (99), Li, X. (87), Nam, K. (78), Zhang, J. (78), Uysal, M. (76), Han, H. (65), Wang, Y. (65), } \\
\text { Kim, J. (61), Davis, F.D. (59), Bagozzi, R.P. (58), Mckercher, B. (57), Morrison, A.M. (57), Park, J. (55), Yoo, C.W. (55), Hair, J.F. } \\
\text { (54), Lee, J. (53), Jung, T. (51), Fornell, C. (50), Huang, C.D. (49), Goo, J. (48), Venkatesh, V. (48), Ajzen, I. (45), Song, H. (44), Li, } \\
\text { J. (43), Kim, H. (42), Liu, Y. (42), Sun, Y. (42), Pan, B. (37), Li, G. (36), Shoval, N. (35), Kim, S. (34), Lee, S. (34), Babin, B.J. (33), } \\
\text { Chen, Y. (33), Kim, C. (33), Larcker, D.F. (33), Bhattacherjee, A. (32), Tom Dieck, M.C. (32) }\end{array}$ \\
\hline 2 (Green) & $\begin{array}{l}\text { Buhalis, D. (847), Ivars-Baidal, J.A. (184), Amaranggana, A. (179), Boes, K. (153), Li, Y. (149), Inversini, A. (138), Baggio, R. (113), } \\
\text { Del Chiappa, G. (106), Femenia-Serra, F. (96), Micera, R. (81), Ritchie, J.R.B. (79), Celdrán-Bernabéu, M.A. (74), Wang, X. (74), Li, } \\
\text { X.R. (63), Mazón, J.N. (63), Fuchs, M. (58), Hu, C. (57), Nijkamp, P. (57), Huang, C. (56), Jovicic, D.Z. (54), Buonincontri, P. (51), } \\
\text { Del Vecchio, P. (50), Perles-Ribes, J.F. (49), Duan, L. (47), Hall, C.M. (47), Caragliu, A. (46), Hopken, W. (45), Crouch, G.I. (44), } \\
\text { Perles-Ivars, A.F. (43), Presenza, A. (41), Zhen, F. (41), Komninos, N. (38), Gossling, S. (37), Del Bo, C. (35) }\end{array}$ \\
\hline 3 (Blue) & $\begin{array}{l}\text { Gretzel, U. (780), Koo, C. (589), Sigala, M. (260), Lamsfus, C. (170), Werthner, H. (149), Hunter, W.C. (104), Zhang, L. (84), } \\
\text { Alzua-Sorzabal, A. (76), Vargo, S.L. (73), Shin, S. (55), Lusch, R.F. (54), Li, N. (49), Martin, D. (44), Torres-Manzanera, E. ( } 38 \text { ), } \\
\text { López de Ávila, A. (34) }\end{array}$ \\
\hline 4 (Yellow) & $\begin{array}{l}\text { Xiang, Z. (417), Fesenmaier, D.R. (331), Wang, D. (237), Neuhofer, B. (175), Tussyadiah, I.P. (172), Ladkin, A. (97), Park, S. (83), } \\
\text { Cobanoglu, C. (42), Pearce, P.L. (39), Benckendorff, P.J. (35), Leung, D. (33), Dickinson, J.E. (32), Moscardo, G. (32) }\end{array}$ \\
\hline
\end{tabular}

$\mathrm{N}$ : Frequency of authors co-citation.

Source: Own elaboration. 
